Department of Wildlife and Zoo Medicine,

Faculty of Veterinary Medicine, Suez Canal University, Ismilia, Egypt.

\title{
PULMONARY AND SUBMANDIBULAR LYMPH NODE ABSCESSES IN A WHITE - TAILED DEER (ODOCOILEUS VIRGINIANUS)
}

(With One Table and One Figure)

\author{
By \\ RABAB AFIFI; J.M. SLEEMAN*; G.K. SAUNDERS** \\ and T. KAUR** \\ * Department of Biomedical Sciences and Pathobiology, \\ Virginia, Maryland Regional College of Veterinary Medicine, USA. \\ **U.S. Geological Survey, National Wildlife Health Center, 6006 Schroeder \\ Road, Madison, Wisconsin 53711, USA. \\ (Received at 3/10/2009) \\ خراجات رئوية والعقدة الليمفاوية تحت القك السفلي في الايل أبيض الذيل \\ (Odocoileus Virginianus)

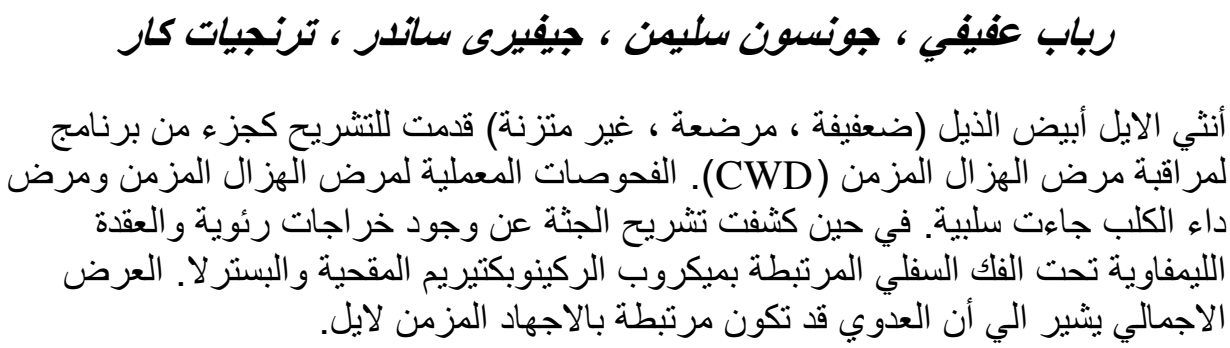

\section{SUMMARY}

A thin, lactating and uncoordinated female white-tailed deer was submitted for necropsy as part of a surveillance program for chronic wasting disease (CWD). Laboratory tests for CWD and rabies were negative. Post-mortem examination revealed pulmonary and submandibular lymph node abscesses associated with Arcanobacterium pyogenes and Pasteurella. The overall presentation suggests that the infections may have been associated with chronic stress.

Key words: Arcanobacterium pyogenes, chronic stress, chronic wasting disease, deer, Pasteurella. 


\section{INTRODUCTION}

Arcanobacterium pyogenes (formely Actinomyces pyogenes and Corynebacterium pyogenes) is nonmotile, facultatively anaerobic, grampositive bacterium (Ames et al., 2002) that can cause a wide variety of nonspecific suppurative lesions invading various visceral organs (Baumann et al., 2001). Arcanobacterium pyogenes produces a range of disease condition in domestic ruminant and wild ruminant including pneumonia, mastitis, abscessation, endocarditis, pyometra, endometeritis and umbilical infection (Davidson et al., 1990). In Cervidae, A. pyogenes has been implicated in fetal pleuropneumonia in (white tailed deer), intracranial abscess in (white tailed deer), mastitis with subsequent disseminated disease in (white tailed deer), chronic fibrinopurulent bronchopneumonia with abscessation in (free ranging Elk), necrobacillosis in (deer and antlelope), foot abscess in (free ranging fellow deer), metritis, endocarditis and abortion in (white tailed deer) as seen on Table 1 .

Table 1: Arcanobacterium pyogenes isolated from cervidae associated with potential stressor and pasteurella infection.

\begin{tabular}{|c|c|c|}
\hline Animal species & Lesion(s) & Potential stressors \\
\hline Mule deer & cerebral abscess $^{\mathrm{a}}$ & parasitic infestation (Johnson et al., 1983). \\
\hline Reindeer & Subcutaneous abscess $^{\mathrm{a}}$ & overcrowding (Zulty and Montali 1988). \\
\hline White tailed deer & intracranial abscess $^{\mathrm{a}}$ & $\begin{array}{l}\text { subcutaneous infection adjacent to } \\
\text { antler pedicle, pedicle fractures } \\
\text { (Davidson } \text { et } \text { al., 1990). }\end{array}$ \\
\hline Elk & $\begin{array}{l}\text { chronic fibropurulent } \\
\text { bronchopneumonia }^{\mathrm{a}, \mathrm{b}}\end{array}$ & predation/hunting (Rhyan et al., 1997). \\
\hline White tailed deer & $\begin{array}{l}\text { Mastitis with subsequent } \\
\text { Disseminated disease }^{\mathrm{a}}\end{array}$ & radio collar (Turnguist and Fales, 1998). \\
\hline White tailed deer & fetal pleuropnemonia $^{\mathrm{a}}$ & $\begin{array}{l}\text { pregnancy, capture, transport (Palmer and } \\
\text { Whipple, 1999). }\end{array}$ \\
\hline White tailed deer & intracranial & $\begin{array}{l}\text { seasonal (breeding and predation); } \\
\text { trauma to antlers and skin (Baumann } \\
\text { et al., 2001). }\end{array}$ \\
\hline iiled deer & mandibular abscess $^{\mathrm{a}}$ & $\begin{array}{l}\text { overcrowding (Chirino-Trejo et al., } \\
\text { 2003). }\end{array}$ \\
\hline $\begin{array}{l}\text { Fallow deer } \\
\text { White tailed deer }\end{array}$ & $\begin{array}{l}\text { foot abscess }^{\mathrm{a}} \\
\text { pneumonia, abscess }^{\mathrm{a}, \mathrm{c}}\end{array}$ & $\begin{array}{l}\text { Humidity; species competition; } \\
\text { predation; handling (Lavin et al., 2004). } \\
\text { handling, overhandling (Haigh et al., } \\
\text { 2005). }\end{array}$ \\
\hline
\end{tabular}

${ }^{\mathrm{a}}$ Arcanobacterium pyogenes

${ }^{\mathrm{b}}$ Pasteurella multocida

${ }^{\mathrm{c}}$ Other genera of bacteria including Pasteurella species 


\section{MATERIALS and METHODS}

A female white-tailed deer (Odocoileus virginianus) was observed on August 1, 2007 in Russell County, Virginia by a field biologist working in conjunction with Virginia's Department of Game and Inland Fisheries (VDGIF). The deer was observed to be very thin and uncoordinated. As part of the VDGIF's targeted surveillance program for Chronic Wasting Disease (CWD), she was euthanized by gunshot and transferred to the Virginia Department of Agriculture and Consumer Services laboratory for post-mortem evaluation. The doe was approximately 7 years old, lactating and thin. Old superficial skin lacerations were found on her right ventral neck. Both submandibular lymph nodes were enlarged and contained abscesses filled with a thick caseous exudate (Figure 1A). Multifocal areas of consolidation and abscesses were present in both lungs; some of the abscesses were approximately $2 \mathrm{~cm}$ in diameter (Figure 1B). There was nasopharyngeal myiasis. The gastrointestinal tract, liver, kidneys, spleen, urinary bladder, uterus and brain were grossly normal.

Brain tissues were removed aseptically and transferred to VDGIF for analysis for CWD and rabies virus. Brain culture swabs were sent to the Virginia-Maryland Regional College of Veterinary Medicine (VMRCVM) for anaerobic bacteria on PRAS Brucella agar plates (Anaerobe Systems, Morgan Hill, California 95037 USA). Brain was cultured for Listeria monocytogenes in BHI Broth (Remel, Lenexa, Kansas 66215 USA) for 12 weeks at $4{ }^{\circ} \mathrm{C}$ with weekly sub-culturing of broth onto Columbia blood agar with $5 \%$ sheep blood (Remel, Lenexa, Kansas 66215 USA).

Submandibular lymph nodes, lung, and intestine were taken aseptically for culture. Samples from lymph nodes were cultured for aerobic bacteria on Tryptic Soy agar, MacConkey agar II, Columbia CNA agar. Lung tissue was cultured for aerobic bacteria on chocolate 2, blood, MacConkey Agar II, and Columbia CNA agar (Becton, Dickinson and Company, Fisher Scientific, Suwanee, Georgia 30024 USA), and for Mycoplasma on PPLO agar (University of California, Davis, California 95616 USA). Salmonella enrichment culture was performed on intestine using Tetrathionate Broth (Becton, Dickinson and Company, Fisher Scientific, Suwanee, Georgia 30024 USA) and Hektoen Enteric agar (Virginia Department of Agriculture and Consumer Services, Wytheville Animal Diagnostic Laboratory, 
Wytheville, Virginia 24382 USA). Blood, Columbia CNA and chocolate agar plates were incubated in $5 \% \quad \mathrm{CO}_{2}$ at $37{ }^{\circ} \mathrm{C}$. Hektoen and MacConkey Agar plates were incubated at $37{ }^{\circ} \mathrm{C}$ with no $\mathrm{CO}_{2}$. PPLO agar plates were kept in a humidity chamber and placed in $5 \% \mathrm{CO}_{2}$ at $37^{\circ} \mathrm{C}$ for 7 days.

Lung, lymph node, brain, spleen, liver, intestine and heart samples were preserved in $10 \%$ neutral buffered formalin for histopathologic examination. Feces and nasopharyngeal samples were taken for parasite analysis. The zinc sulfate flotation method was used for fecal analysis and parasite identification was done by microscopic examination (Zajac et al., 2002).

\section{RESULTS}

Arcanobacterium pyogenes was isolated from lung and submandibular lymph node, and identified using bioMérieux API Coryne strips (bioMérieux, Inc., Durham, North Carolina 27712, USA). Pasteurella spp. was isolated from the same lymph node, and identified using bioMérieux API 20 NE strip (bioMérieux, Inc., Durham, North Carolina 27712, USA). Laboratory tests for rabies, CWD, Listeria, Mycoplasma, Mycobacterium and Salmonella were all negative. Histopathologic examination was performed on lung, brain, spleen, lymph node, intestine, heart and liver. The intestine was severely autolyzed. The lung had multiple discrete nodules of coagulative necrosis containing neutrophils and macrophages (Figure 1C). A rim of neutrophilic inflammation surrounded the necrosis; peripheral to this was a layer of fibroplasia and fibrosis. A few nodules contained fibrin circumscribed by fibrosis. Alveoli adjacent to the nodules were distended with foamy, pale basophilic fluid or filled with fibrin. Between the nodules, lung tissue had neutrophils, macrophages and fibrin filling alveoli. The brain had a single focus of hemorrhage within the cerebral cortex adjacent to the lateral ventricle. No reaction to the hemorrhage was seen. Nasopharyngeal myiasis was identified as Cephenemyia spp. (nasal bot) and Trichostrongylus spp. was found in the feces. 


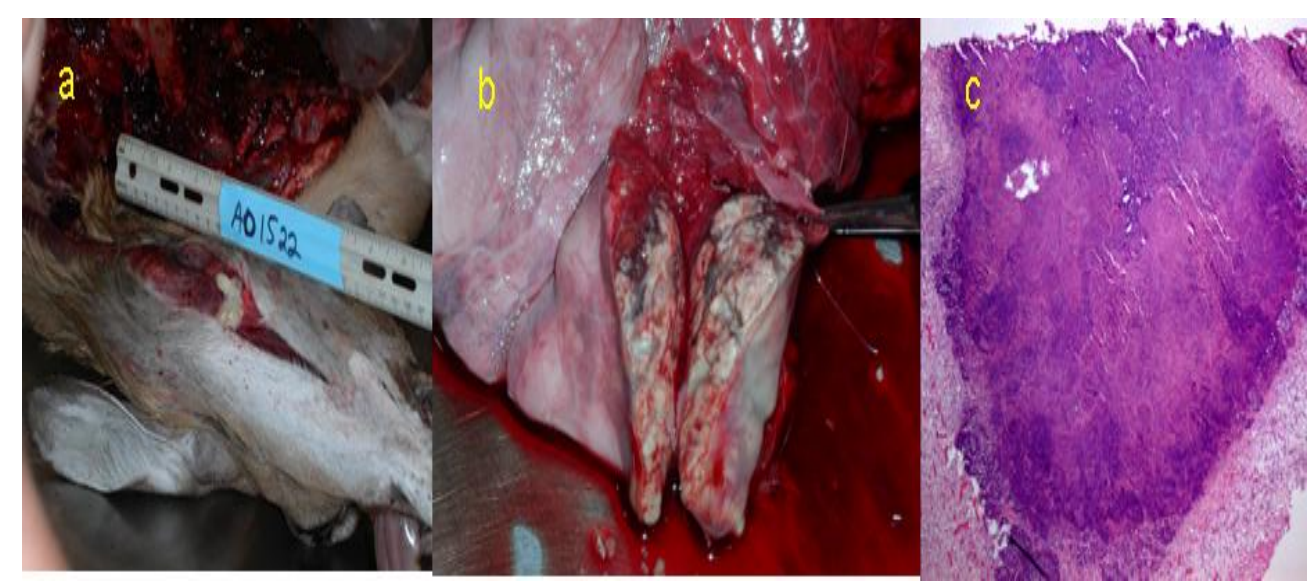

Fig. 1: Pulmonary and submandibular lymph node abscesses associated with Arcanobacterium pyogenes in a white-tailed deer (Odocoileus virginianus).

A. Arcanobacterium pyogenes and Pasteurella were cultured from submandibular lymph node abscesses.

B. Pulmonary abscess and multifocal areas of consolidation due to A. pyogenes.

C. Section of lung with fibrinopurulent and necrotizing bronochopneumonia due to mixed Pasteurella and A. pyogenes infection; a discrete nodule of coagulative necrosis (arrows) containing neutrophils and macrophages $(\mathrm{Bar}=25 \mu \mathrm{m})$.

\section{DISCUSSION}

Pasteurella is a common commensal in the upper respiratory tract of domestic and wild animals (Jaworski et al., 1998). It is the most common cause of pneumonia in ruminants. Isolation of Pasteurella from the submandibular lymph node suggests that it was in the doe's lung at one time. A. pyogenes, generally an opportunistic organism mainly presenting as a mixed infection in stressed animals, may have entered the doe's body through neck lacerations or compromised nasal and gastrointestinal mucosa. In conclusion, even though it was not isolated from the lung, Pasteurella was the primary cause of infection in the lung and from there it spread to the lymph node. A. pyogenes was considered to be a secondary infection in the lungs where pneumonia was already present. The final diagnosis was pulmonary and lymph node abscesses due to $A$. pyogenes and fibrinopurulent and necrotizing 
bronochopneumonia due to a mixed Pasteurella and A. pyogenes infection. Based on the doe's history and presentation, some combination of stressors likely led to chronically high stress levels sufficient to suppress the doe's immune response, thereby allowing Pasteurella and A. pyogenes to become established in lung and lymph nodes, and cause the fulminant bronchopneumonia. Table 1 lists previously reported clinical cases of A. pyogenes infection reported in cervidae with exposure to potential stressors and in some cases, Pasteurella co-infection, including cases with abscesses in free ranging white-tailed deer.

Acknowledgment(s): The authors thank the Virginia Department of Agriculture and Consumer Services, Wytheville Animal Diagnostic Laboratory and J. Wills, Virginia Department of Game and Inland Fisheries for assistance with this case.

\section{REFERENCES}

Ames, T.R.; Baker, J.C and Wikse, S.E. (2002): The Bronchopneuomias. In Smith B.P (ED). Large animal Internal Medicine, $3^{\mathrm{RD}} \mathrm{ED}$, Mosby INC., St. Louis., Missouri. PP. 551-552.

Baumann, C.D.; Davidson, W.R.; Roscoe, D.E. and Beheler-Amass, K. (2001): Intracranial abscessation in white-tailed deer of North America. J. Wildl. Dis. 37: 661-670.

Chirino-Trejo, M.; Woodbury, Woodbury, M.R. and Huang, F. (2003): Antibiotic sensitivity and biochemical characterization of Fusobacterium spp. and Arcanobacterium pyogenes isolated from farmed white-tailed deer (Odocoileus virginianus) with necrobacillosis. J. Zoo Wildl. Med. 34: 262-268.

Davidson, W.R.; Nettles, V.F.; Hayes, L.E.; Howerth, E.W. and Couvillion. Couvillion, C.E. (1990): Epidemiologic features of an intracranial abscessation/suppurative meningoencephalitis complex in white-tailed deer. J. Wildl. Dis. 26: 460-467.

Haigh, J.; Bere, Zowski, J. and Woodbury, M.R. (2005): A crosssectional study of the causes of morbidity and mortality in farmed white-tailed deer. Can. Vet. J. 46: 507-512.

Jaworski, M.D.; Hunter, D.L. and Ward, A.C. (1998): Biovariants of isolates of Pasteurella from domestic and wild ruminants. J. Vet. Diagn. Invest. 10: 49-55. 
Johnson, J.L.; Campbell, J.B.; Doster, A.R.; Nason, G. and Cagne, R.J. (1983): Cerebral abscess and Cephenemyia phobifer in a mule deer in central Nebraska. J. Wildl. Dis. 19: 279-280.

Lavin, S.; Ruiz-Bascaran, M.; Marco, I.; Abarca, M.L.; Crespo, M.J. and Franch. J. (2004): Foot infections associated with Arcanobacterium pyogenes in free-living fallow deer (Dama dama). J. Wildl. Dis. 40: 607-611.

Palmer, M.V. and Whipple, D.L. (1999): Arcanobacterium pyogenes as a cause of fatal pleuropneumonia after capture and transport of white-tailed deer (Odocoileus virginianus). J. Vet. Diagn. Invest. 11: 468-471.

Rhyan, J.C.; Aune, K.; Ewalt, D.R.; Marquardt, J.; Mertins, J.W.; Payeur, J.B.; Saari, D.A.; Schladweiler, P.; Sheehan, E.J. and Worley, D. (1997): Survey of free-ranging elk from Wyoming and Montana for selected pathogens. J. Wildl. Dis. 33: 290-298.

Turnquist, S.E. and Fales. W.H. (1998): Disseminated Actinomyces pyogenes infection in a free-ranging white-tailed deer. J. Vet. Diagn. Invest. 10: 86-89.

Zajac, A.M.; Johnson, J. and King. King, S.E. (2002): Evaluation of the importance of centrifugation as a component of zinc sulfate feacal flotation examinations. J. Am. Anim. Hosp. Assoc. 38: 221-224.

Zulty, J.C. and Montali, R.J. (1988): Actinomyces pyogenes infection in exotic Bovidae and Cervidae: 17 cases (1978-1986). J. Zoo Anim. Med. 19: 30-32. 